\title{
GEOGRAFÍA MÍTICA DE LA GRECIA ANTIGUA (II)
}

\author{
Máximo Brioso Sánchez.
}

El conjunto del mundo sólido, de las tierras que conformaban una especie de inmensa isla, parece haberse concebido como rodeado por un gran río llamado Océano. De nuevo surge así el concepto de la insularidad como motivo mítico esencial. Pero esta gran isla bio tricontinental no está ceñida por el mar, puesto que el mar por antonomasia era el

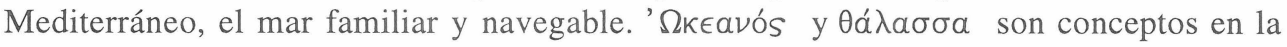
práctica irreductibles, mito frente a realidad, por más que esta oposición, sin que ello nos sorprenda, no aparezca nunca así expresada. Tampoco el Océano, según una interpretación posible, sería identificable fácilmente con entidades geográficas como el Atlántico o el Índico, al tratarse de un concepto ancestral de muy difícil asimilación a los crecientes conocimientos geográficos. De hecho, que sepamos, no hay texto alguno muy antiguo donde se dé una identificación explícita semejante entre el Atlántico y el Océano, pero tampoco donde se niegue. Esto hubiera supuesto poder distinguir con precisión el ámbito mítico del real y, de hecho, forzar una ubicación concreta para el Océano, cuando éste era por su propia esencia inaccesible a los humanos en condiciones normales. Y hemos de esperar a la crítica racionalista de Heródoto para que aflore tal identificación. Por tanto, sería bastante inimaginable que un navegante, por ejemplo, como Coleo de Samos (cf. Hdt. 4.152) al traspasar el Estrecho de Gibraltar se dijese que estaba penetrando en el Océano. Y probablemente también que se plantease el problema: él no era ni Heracles ni Odiseo. La consideración del Atlántico como el Océano será un hecho posterior, cuando ya el concepto del Océano mítico haya cedido el paso a una visión científica. Era ésa una identificación seguramente tan inconcebible en aquel tiempo, según esta interpretación, como la de preguntarse si el agua del Océano era dulce o salada, una pregunta que, según nuestras noticias, tampoco se hicieron nunca los antiguos y que en cambio para nosotros es bien natural. Un lugar mítico está, pero de él no siempre se podrá decir que está justamente ahí. Cualquier precisión geográfica en el terreno mítico puede ser meramente ilusoria. Así, en la Odisea, como ya hemos recordado, la isla de Calipso está en el "ombligo del mar", con lo que suponemos que se nos está indicando que está en su mismo centro, y se nos precisa que desde ella y navegando siempre hacia el Este durante diecisiete días Odiseo arriba a Esqueria. Pero todos estos datos flotan en el vacío mítico y resulta difícil aceptar la tesis de Bérard y 
L. Moulinier ${ }^{1}$ de un punto concreto de las costas cercanas al Estrecho de Gibraltar, simplemente, como argumento de mayor peso, porque Calipso sea hija de Atlas. El único dato aprovechable de la Odisea al respecto es la dirección Oeste y el que, tanto a la ida como al retorno, se trate de la navegación más larga del poema. La ubicación, ya sea dentro o fuera del Mediterráneo, la ponemos nosotros.

El Océano como río circular, anular, rodea, pues, todas las tierras, según una concepción que no es exclusiva en absoluto de la cultura griega ${ }^{2}$. Una de sus orillas es el límite del mundo. La otra, sin embargo, es un enigma y debería ser en cierto modo inconcebible, ya que lógicamente quien navegue por el Océano sólo podrá desembarcar en la orilla de acá, nunca en la de allá, donde no es imaginable la existencia de otra tierra firme semejante. Es "le mystère ou le scandale d'un Océan pourvu d'un seul rivage", en palabras de Ballabriga (ibid.), y no obstante no faltan ocasiones en que se nos hable de "atravesar" el Océano o de un lugar "más allá" del Océano (así en Hesíodo, Th. 215), pero que no es naturalmente ya un ámbito humano. Ni cabe preguntarse por la dirección de su corriente: fluye sobre sí mismo, su curso es circular como perfecta imagen del eterno retorno. No se nos dirá dónde está su confluencia con el mar navegable, pero, cuando Odiseo regresa del Hades, su nave pasa con la naturalidad más asombrosa del uno al otro $(O d .12 .1 \mathrm{~s}$.). Es el fácil tránsito tantas veces sin solución de continuidad del mundo mítico al real. En el Océano se bañan las estrellas cuando descienden por el firmamento, por lo que aparece igualmente como una frontera entre el ámbito terrestre y la bóveda celeste. Y de un modo que nunca se explica tampoco el Sol viaja por él o lo "atraviesa" durante la noche, cuando de algún modo jamás precisado aparece como invirtiendo su ruta diurna, de occidente a oriente (una cuestión sobre la que habremos de volver), para estar por la mañana en su puesto y reemprender su camino. Los varios textos poéticos que se refieren a ese viaje nocturno (de la Odisea, de Estesícoro, de Mimnermo) son, como era de esperar, de una extrema vaguedad. El Océano, también naturalmente y como se nos recuerda en diversas ocasiones, está vedado a los hombres, que sólo acceden a él y navegan por sus aguas, como Odiseo, bajo el amparo divino. Cuando los héroes de Apolonio de Rodas se aventuran por los cursos fluviales europeos hacia el enigmático Norte y están a punto de alcanzar el Océano, el poeta nos dirá que "de allí no hubieran retornado sanos y salvos" (4.636 ss.), a pesar de ser héroes míticos y no simples humanos. En sus orillas se sitúa el Más Allá, el reino de los muertos. A su vez, Océano, además de ser el origen de "todos los ríos, todo mar, todas las fuentes y todos los pozos profundos" (Il. 21.196 s.), es también "el origen de todos los seres" (Il. 14.246), posiblemente porque es concebido como el origen de todas las aguas ${ }^{3} \mathrm{y}$, quizás como un antecedente del planteamiento de $\mathrm{Tales}^{4}$, porque a éstas se asociaba el fenómeno de la existencia. Las corrientes de agua emanan todas de él, según una visión en la que las aguas

\footnotetext{
${ }^{1} \mathrm{Cf}$. de éste último Quelques hypothèses relatives à la géographie d'Homère dans l'Odyssée (Aix-en-Provence 1958) $107 \mathrm{~s}$.

2 Cf. Ballabriga, Le soleil, 65 .

${ }^{3}$ Cf. el catálogo de los ríos que nacen de Océano en Hesíodo, Th. 337 ss.

${ }^{4}$ Cf. F. Buffière, Les mythes d'Homère et la pensée grecque (Paris 1973) 86-88.
} 
confluyen hacia un centro, el Mediterráneo, desde la remota periferia que constituye el Océano ${ }^{5}$. Éste, por consiguiente, desde tal perspectiva es más una realidad cósmica que meramente geográfica ${ }^{6}$, terrestre, por lo que es inútil imaginarlo supeditado a los condicionamientos de la naturaleza observable.

Ahora bien, esta concepción que aquí hemos esbozado ha sido discutida más de una vez por algunos estudiosos modernos como Hennig o Arrighetti, para los que la identificación del Océano con el Atlántico es un hecho aceptable y por consiguiente domina en su concepto la valoración geográfica sobre la cósmica. El problema es muy complejo, en parte ya por el reducido marco que implica el antiguo concepto de cosmos y en parte porque está ligado a la inacabable polémica en torno a la ubicación de los lugares odiseicos, y sobre todo de algunos de ellos tan relevantes como la isla de Circe y el Hades, así como al asentamiento de los Cimerios o los Lestrígones, es decir los más relacionados con la cuestión oceánica. Los datos homéricos son de una tan asombrosa imprecisión como para situar una vez la isla de Circe con aparente claridad "donde está la morada de la Aurora y los lugares donde nace el Sol" (Od. $12.3 \mathrm{~s}$.) y otra en cambio en un paraje en el que Odiseo confiesa con desánimo (10.190 ss.) que no hay medio de orientarse, "pues no sabemos dónde la oscuridad ni dónde el alba ni por dónde se dirige bajo la tierra el Sol que es luz para los mortales ni por dónde asciende". Tantas vaguedades y contradicciones explican el relativo escepticismo de un autor como A. Lesky ${ }^{7}$, en un extenso artículo que permanece hoy todavía como referencia obligada para todos los estudiosos del tema, o la perplejidad de un recalcitrante "topógrafo" homérico como Bérard, que sin embargo se decidió por un lugar tan poco apropiado como la costa napolitana. Es debatido, por ejemplo, si Odiseo navega desde la isla de Circe en dirección occidental hasta el Océano y el Hades o si ha de circunnavegar la tierra por el Océano desde el Oriente, donde para muchos ${ }^{8}$ es materia segura que debe estar situada la mencionada isla, sobre todo por la estrecha relación tradicional entre Circe y el $\mathrm{Sol}^{9}$. Ha de reconocerse que posiblemente el único lugar homérico donde el Océano es descrito como un río anular en torno a la tierra sea $I l .18 .607$ s., en la hoplopoiía, y que en el resto de los pasajes la ubicación parece ser más bien simplemente occidental. Pero los datos no son tan precisos como Arrighetti y otros creen poder afirmar. Sin embargo, ha de admitirse igualmente que la geografía homérico-hesiódica está cifrada en un interés básico hacia Occidente ${ }^{10}$, en contra de quienes prefieren ver en ella una doble

\footnotetext{
5 Cf. aún Pl. Phd. 111 d ss.

${ }^{6}$ Es la conclusión muy razonable de J. Rudhardt, Le thème de l'eau primordiale dans la mythologie grecque (Berne 1971) 77 ss.

7 "Aia", WS 63 (1948) 22-68 (=Gesammelte Schriften, Bern 1966, 26 ss.).

8 Cf. por ejemplo Mouliner, op. cit., 77 ss., contra una corriente antigua representada por un autor como Estrabón (1.2.18), que situaba este punto del fabuloso mundo odiseico en el remoto Occidente, en el Atlántico, o en todo caso en el Oeste del Mediterráneo.

${ }^{9}$ Cf. la exhaustiva discusión del tema por G. Arrighetti en el excelente libro colectivo editado por él mismo Esiodo. Letture critiche (Milano 1975) 146-213. Ahí se encontrará también citada la bibliografía más pertinente, que aquí podemos por tanto en su mayor parte ahorrarnos mencionar.

${ }^{10}$ Cf. Arrighetti, op. cit., 177 ss. sobre todo.
} 
orientación, tanto hacia el Oeste, por supuesto, como hacia el Este, en concreto hacia las orillas del Ponto. Pero el propio Arrighetti se ve forzado a aceptar que la identificación del Océano con el Atlántico no invalida en absoluto ni se contradice con la concepción anular de aquél, que, ha de añadirse, queda confirmada sobre la base de la tradición recogida en Heródoto. Así que o bien, como quieren Arrighetti y sus predecesores en esta tesis, fue ya muy antigua la identificación entre el Océano mítico y el Atlántico, para lo que debemos remontarnos a una situación en que los griegos tuvieron muy vagas noticias sobre un gran mar más allá de las Columnas de Hércules, o bien fue más tarde cuando a partir de una vieja concepción mítica de un Océano anular, compartida con otros pueblos, se pasó por un fácil proceso de asimilación a la idea de un océano exterior (el Atlántico), por oposición al mar interior que era el Mediterráneo, y concebido gradualmente como un puro concepto geográfico y por tanto representable sobre un mapa: esto sería lo que atestiguaría tanto la noticia de Heródoto (4.36) sobre cierta clase de balbuceos cartográficos en su época, con la circulación de sencillos mapamundis en que se trazaba el gran anillo oceánico todavía en torno al conjunto de las tierras, como también su referencia a la isla de Gerión, cercana a Gades y "situada en el Océano" (4.8), y su crítica a las opiniones de quienes hacían provenir las aguas del Nilo precisamente del mismo Océano (2.21). Pero el tema se complica aún más cuando interviene la cuestión de la ubicación del Hades. Una materia esta, la de la situación de las regiones infernales, que no tendría sentido que se planteara en un estudio de geografía real, pero que sí lo tiene en una indagación en el terreno de la geografía mítica. Ultratumba es para los antiguos un lugar concreto, no una abstracción propia del dominio espiritual.

Ya hemos visto cómo el Más Allá ${ }^{11}$ se asocia al concepto del Océano, incluso en la nota común de ser dos ámbitos inaccesibles al hombre. Ambos aparecen como entidades míticas mayores, éste como el límite del mundo de la vida, aquél como reino de la muerte. Su vinculación por tanto es de una extrema coherencia, como lo es que el Más Allá esté justamente en las orillas mismas del Océano. La ruta que conduce del mundo de los vivos al de los muertos es, no obstante, como vemos en la Odisea y como no podría ser de otro modo, vaga e imprecisa. Según las instrucciones de Circe, Odiseo navega con sus compañeros (10.507 ss. y 11.10 ss.), impulsados por el Bóreas y suponemos que a una velocidad prodigiosa, en una sola jornada, hasta pasar el Océano y el país de los Cimerios y arribar a la confluencia del Aqueronte y otros ríos infernales. El dato del soplo favorable del Bóreas debería ser esclarecedor en otras condiciones, pero aquí no es sino un elemento más en un complejo juego de equívocos que ha traído de cabeza a los comentaristas desde siempre. En cuanto al otro dato, también aparentemente ilustrativo, de la situación de los Cimerios, se revela por igual confuso en extremo. Es una notable coincidencia tal vez el hecho de que la llegada de los navegantes odiseicos al Hades, o más bien sólo a su entrada, ocurra en el momento de la puesta del Sol y que a la vez los Cimerios sean un pueblo que vive en una especie de crepúsculo o noche perpetua, ya que, según 11.15 s., el Sol nunca

\footnotetext{
11 De este tema el autor ha tratado por extenso en su contribución a un volumen colectivo sobre el Más Allá en diversas culturas de próxima publicación por la Universidad de Sevilla.
} 
dirige hacia ellos su mirada. Parece darse ahí, como refuerzo de la oposición vida/muerte, una oposición entre la luz solar y la oscuridad, y por tanto una relación, nunca explicada, entre los Cimerios y el reino de la muerte. No han faltado quienes hayan querido situar a estas gentes enigmáticas en el remoto Norte, y también ha sucedido lo mismo con los Lestrígones, en este caso al menos desde Crates $^{12}$, y sin reparar apenas en las diferencias esenciales entre los dos tipos de población mítica que representan unos y otros. Respecto a éstos últimos, los Lestrígones, de etimología muy incierta y en un episodio de fuertes notas folclóricas, parece sin embargo bastante claro que el texto homérico no induce precisamente a creer en esa posición nórdica, puesto que el lugar donde "están cercanos los caminos de la noche y del día" (Od. 10.86) sería más razonable que respondiese a uno de los extremos oriental u occidental, en que de algún modo sí puede afirmarse que la noche y el día mantienen su mayor proximidad posible, es decir con una "neutralización meteorológica" en sentido lato, mejor que, como afirman algunos, en la forma de un día perpetuo. Y, sin embargo, nuestros osados "topógrafos" modernos no han tenido reparos en señalar puntos específicos dentro del Mediterráneo occidental, en la zona de Córcega y Cerdeña (Bérard, Carpenter, Pocock, Moulinier, etc.) o en diversos lugares de las costas entre el Norte de África y el Mar Negro, y naturalmente con el dudoso apoyo de ciertas tradiciones antiguas $^{13}$. Aquélla es en cambio al menos hasta cierto punto la tesis defendida por $\mathrm{H}$. $\operatorname{Vos}^{14}$, según el cual hay que situar a los Lestrígones en el extremo Este, donde el cielo alto y claro (aîńp) "toca" el horizonte y la luz neutraliza la oposición natural día-noche. Para nosotros el texto homérico subraya el carácter utópico de neutralización de opuestos, en un lugar del que se celebra un prodigio económico. Por ello no vemos aceptable ni la coincidencia de su ubicación con la de los Cimerios, como cree Vos, ni la analogía que cree hallar Arrighetti (op. cit., p. 154) entre ambos pueblos homéricos. Ese carácter utópico se refuerza, si se admite una comparación tal, con la semejanza de su situación con la de los Bienaventurados en Píndaro (O. 2.61 ss.), donde se lee que el Sol "hace iguales las noches a días iguales siempre"15. Por lo que se refiere a los Cimerios, la discutible ubicación nórdica

\footnotetext{
12 Nombres ilustres que han compartido esta opinión son los de Lesky, F. Gisinger (éste en su acreditada contribución, que ya hemos mencionado, a la $R E$, 534) y los editores K. F. Ameis y C. Hentze. Sobre la debilidad de sus argumentos cf. H. Vos, "Die Bahnen von Nacht und Tag", Mnemosyne S. IV, 16 (1963) 18-34. La polémica está resumida en Arrighetti, op. cit., 149 ss. La ubicación intramediterránea (Bonifacio, en Córcega, sobre todo: así todavía autores como Moulinier y Dion) creemos que debe por principio excluirse. No es claro en modo alguno que los Lestrígones tengan ese aire de colonos que Dion (en su libro citado, 105) les atribuye; no practican la agricultura y, si bien poseen un excelente puerto, no es seguro que sean navegantes, de suerte que su puerto parece más bien un atractivo cebo en que los incautos son pescados como atunes en una almadraba. Viven de sus capturas sin duda y la antropofagia es una nota siniestra y expresiva de un mundo totalmente aparte, comparable en cierto modo al de los Cíclopes.

13 Cf. por ejemplo Tucídides 6.2 para la localización siciliana.

14 Art. cit. Su decisión de ubicar a los Cimerios en el mismo ámbito nos parece errónea: las condiciones en que viven éstos son inversas, porque entre ellos, por la eterna no presencia del Sol, reina la oscuridad. El punto de partida falso de Vos es su identificación de los Cimerios homéricos con los históricos (p. 23).

15 Sobre este pasaje pindárico y sus implicaciones cf. L. Woodbury, "Equinox at Acragas": Pindar Ol. 2.61-62" (TAPhA 97, 1966, 597-616), el cual sigue en lo esencial a Vos. A su vez se ha de notar que este carácter paradisiaco en Píndaro del Más allá de los Bienaventurados recuerda el descrito entre los Hiperbóreos por Baquílides (3.59), en un pasaje al que nos referiremos después, cuando toquemos el tema de este pueblo mítico.
} 
ha estado guiada sin la menor duda, como hemos señalado en el caso de Vos, por el recuerdo de los Cimerios históricos de los que hablan los documentos asirios, un pueblo al parecer de origen iranio, emparentado con los Escitas, y que se desplazó desde el Norte hasta establecerse en la Capadocia Póntica en torno a los comienzos del siglo VIII ${ }^{16}$. Pero la relación entre estos Cimerios históricos y los mencionados en la Odisea es totalmente nebulosa y hay que concluir por ahora que éstos últimos tienen todo el aire de ser una entidad exclusivamente mítica, asociada, por una razón que desconocemos, a las regiones oceánicas e infernales ${ }^{17}$. Y es que en el Hades homérico-hesiódico existe una amalgama de elementos, lo que suele ser olvidado, pero que puede justificar la presencia de ingredientes si se quiere incluso de lo más contradictorios, como ocurre sobre todo con el viaje nocturno del Sol, que está estrechamente vinculado a la posición del Hades. Ha de recordarse que en tiempos antiguos y aún durante la etapa de la colonización jónica, entre los siglos VIII y VI, la tierra era imaginada como un disco plano, en tanto que sólo desde el siglo V está atestiguada la hipótesis de la esfericidad ${ }^{18}$. Por tanto no sabemos bien cómo era concebido ese viaje del Sol durante la noche, del que se habla como una navegación, tal como ocurre igualmente en una mitología como la egipcia. La idea de una vía de Oeste a Este por debajo de la tierra, por nuestras antípodas, estaría, pues, excluida, y esto parecería confirmado por Estesícoro ${ }^{19}$, que alude a cómo el Sol en una copa de oro navega simplemente "atravesando el Océano". Pero esta travesía del Océano, que le lleva sin que podamos saber cómo, hasta el Oriente (¿en una semicircunferencia, según nuestra concepción geométrica?), es al tiempo un viaje por el reino de la noche. Luz y oscuridad se neutralizan así misteriosamente, y esto es lo que parece que podría significar Hesíodo con el encuentro del Día y la Noche personificados (Th. 748 ss.). Tal como dice Ballabriga ${ }^{20}$, también así se neutraliza la oposición Este/Oeste, aunque este autor (p. 106) da por supuesto lo que para otros lógicamente debería excluirse: la vía subterránea, que para él es también a la vez nocturna y oceánica. Se enfrentan, por consiguiente, dos interpretaciones: una, identificable, por citar algunos nombres, con autores como Arrighetti o W. Karl21, según la cual el Hades y todo lo que conlleva estaría situado en Occidente; otra, propia de quienes como Ballabriga admiten una imagen de un acceso subterráneo y que naturalmente tienen su principal apoyo en Hesíodo. Es innegable que en la obra de éste puede hablarse de un verdadero edificio

16 Cf. R. Ghirshman, "Les Cimmériens et leurs Amazones", Actes de VII Congrès de la Fédération Internationale des Associations d'Etudes Classiques I (Budapest 1984) 47-52.

17 Todavía algún autor como Ballabriga (Le soleil, 132 ss.) se empeña en mantener alguna relación entre los Cimerios históricos y los míticos, forzando una muy endeble posición nórdico-oriental, lógicamente ligada a la ubicación oriental de la isla de Circe.

18 La atribución de esta idea ya a Homero por autores antiguos como Crates o Estrabón es un franco anacronismo: cf. G. Aujac, Strabon et la science de son temps (Paris 1966) $23 \mathrm{~s}$.

19 Cf. D. L. Page, Supplementum Lyricis Graecis (Oxford 1974), fr. 17. Cf. Lesky, art. "Aia" ya citado, sobre todo 31 ss.

${ }^{20}$ Le soleil, 79 ss. y 103 ss.

21 Cf. de éste su Tesis Chaos und Tartaros in Hesiods Theogonia (Erlangen-Nürnberg 1967) 95 ss. Algunas referencias más pueden encontrarse en el comentario de A. Heubeck a Od. 24.11-14 en la reciente edición de la Odisea en Mondadori (vol. VI, Milano 1987). 
cósmico, por supuesto finito, en cuyo nivel inferior hay una especie de "abismo" cosmogónico ${ }^{22}$, una visión de la que hay también alguna presencia en Homero: así, en $\mathrm{Il}$. 8.13 ss., en que Zeus amenaza con arrojar a los dioses desobedientes "al brumoso Tártaro, allá bien lejos, donde está la más profunda sima bajo la tierra, donde las puertas de hierro y el umbral de bronce, tan por debajo del Hades cuanto el cielo dista de la tierra"23. El Tártaro sería el fondo de ese abismo y no importa demasiado ahora que en Homero parezca ser, no el Más Allá residencia de los muertos, sino un grado aun más remoto y profundo que el propio Hades, un lugar reservado especialmente para castigo de los Titanes y de los propios dioses. En cambio en la descripción del Más Allá en $O d$. 11 sólo la oscuridad en que viven los Cimerios podría recordar esa ubicación, pero se justifica mucho mejor por la situación en el ocaso. Por lo que respecta a la Teogonía (720-725), se establecen también de un modo semejante las proporciones en las distancias de tres niveles, en una estratificación que se reencuentra en $I l$. 20.56 ss.: los dominios superiores de Zeus, los intermedios y terrestres de Posidón y los subterráneos como morada de los muertos, y coincidente con el Tártaro de otros textos ${ }^{24}$. Así pues, si en pasajes como los ya mencionados de los cantos X y XI de la Odisea puede aceptarse sin más, como quiere Arrighetti, una localización occidental del Hades, en otros lugares épicos, como se ve forzado a reconocer el mismo autor (p. 185) y según ya señalaran filólogos como Kopp y otros, la ubicación occidental es más que discutible. Dentro de la amalgama de que hablábamos en la épica arcaica parecen coexistir al menos dos representaciones del Hades, la occidental, si hacemos caso de la que cabe aceptar como la opinión más razonable, y la subterránea. Algunos como Kopp se han inclinado por el corolario de que la concepción occidental no sea ya sino un mero residuo de creencias en retroceso, en tanto que Arrighetti prefiere entender que es la predominante (p. 201). Para nosotros es éste un problema que puede seguir discutiéndose, pero es aquí y ahora secundario. Lo más notable en cambio quizás sea la convivencia de esa estratificación citada, que ha recibido una explicitación en el mito del reparto divino del universo ${ }^{25}$, con la imagen del Tártaro infernal subterráneo (si es éste el término preciso), y la de la tierra aún como un sólido disco plano y cubierto por la bóveda celeste. Muy posiblemente el punto de unión haya que buscarlo en una borrosa concepción en que se identificaba el límite del mundo, oscuro y muchas veces siniestro, con un ámbito a la vez soterraño, tal como se lee, por ejemplo, en $I l .8 .477$ ss., donde "los extremos confines de la tierra y el mar", huérfanos de

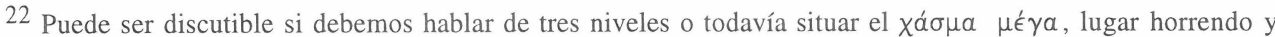
proceloso, en un cuarto nivel. El tema es muy complejo y son recomendables en particular los análisis de G. S. Kirk ("The Interpretation of Hesiod 'Theogony' 736 ff.", PCPhS N. S. 4, 1956-57, 10-13), de Ballabriga (libro citado, 257 sobre todo) y de M. D. Northrup, "Tartarus revisited: A Reconsideration of Theogony 711-819", WS N. F. 13, 1979, 22-36. En cuanto a la tesis de R. Mondolfo (L'infinito nel pensiero dell'antichità classica, Firenze 1956, $2^{\text {a }}$ ed., 278) de que en el chaos hesiódico estaría ya implicada la concepción del infinito, tuvo ya en su momento una respuesta crítica en F. Solmsen, "Chaos and Apeiron", SIFC N.S. 24 (1950) 235-248. Ese nivel

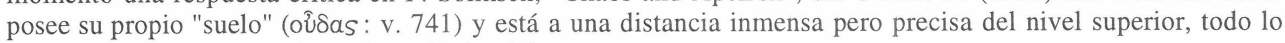
cual supone el reconocimiento de un límite del cosmos.

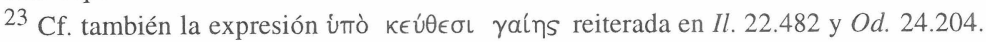

24 Sobre la posible dependencia de esta concepción de cosmogonías orientales cf. U. Hölscher en Esiodo. Letture critiche ya citado, 127-145.

25 Cf., por ejemplo, Il. 15.187 ss.
} 
los rayos del Sol, se funden con "el profundo Tártaro". Una confusión esta de 1o remotamente occidental y lo subterráneo que veremos reaparecer en el mito de las Hespérides.

Señalábamos antes como dos notas básicas del objeto de la imaginación mitificadora el aislamiento y la distancia. Pero en el caso griego concreto, del que ya hemos comentado su marco vital mediterráneo y costero, no sólo es la isla la que aparece como escenario mítico privilegiado, tal como muestra sobre todo la Odisea, sino también las tierras interiores, continentales, entendidas como inaccesibles, oscuras y con frecuencia remotas o incluso extremas. Están pobladas por gentes en que la, en ocasiones, posible realidad se mezcla con la fantasía, apareciendo como en una procesión fabulosa entidades etnológicas como los ya citados Cimerios y Lestrígones (que todavía, como los Feacios, se asocian al concepto del agua, como pueblos costeros o ribereños del propio Océano), los Colcos, las Amazonas, los Etíopes, los Pigmeos, los Hiperbóreos, etc., o criaturas tan notables como las Hespérides. No es cuestión de pasar revista aquí a tantos que aparecen nombrados en Homero, Hesíodo, Heródoto y en decenas de otros autores durante siglos y que forman un inacabable repertorio mítico-paradoxográfico. Pero sí podemos concentrarnos en esos pocos mencionados, muy significativos, en los que las trazas míticas tengan rasgos de especial interés y que sin duda, además, coincide que son aquéllos sobre los que se ha acumulado una más nutrida bibliografía. Trataremos de seguir un cierto orden, si se quiere geográfico, comenzando por los que de algún modo aparecen asociados al Este, aunque muy pronto veremos confirmada la sospecha, que ya se apuntó en el caso de los Cimerios y de la isla de Circe, de que una estricta orientación no es precisamente siempre compatible con las ubicaciones míticas, sino más bien con frecuencia lo contrario, y también de que los pobladores del mundo mítico suelen poseer una tal propensión al nomadismo que parecen más inquietos aún que muchos de los propios pueblos reales de que nos da cabal cuenta la historia antigua. Lo segundo puede tener en algunos casos una explicación particular, pero por lo que se refiere a lo primero ha de tenerse en cuenta el hecho fundamental de que la dependencia de unas referencias como, principalmente, la del Sol conlleva una natural vaguedad, de modo que es explicable, por ejemplo, que el término que corresponde a su salida y ascenso (ảvato入aí) se utilice por lo general así, en plural, como "las salidas" del Sol, los diversos y sucesivos "Orientes", e igualmente que una confusión, sobre todo, entre el Este y el Sur, o entre el Oeste y el Norte, sea de lo más corriente. Como dice Janni en un trabajo en que se ejemplifican en el caso de Pausanias los usos típicos de los griegos ${ }^{26}$, "per gli antichi, 'verso sud' significava l'attributo di un'area sita verso il lato del sole di mezzogiorno" (p. 90), es decir con un tipo de orientación que operaba no con imágenes cartográficas, como entre nosotros, sino con referencias tan imprecisas y estacionalmente cambiantes como la luz y la oscuridad.

26 "Gli antichi e i punti cardinali: rileggendo Pausania", en el colectivo ГЕ ГРАФІ А. Atti del Secondo Convegno Maceratesse su Geografia e cartografia antica (Roma 1988), editado por P. Janni y E. Lanzillotta, 77-91. Cf. también sobre el tema de la orientación el libro ya mencionado de Ballabriga, así como el artículo, muy rico en sugerencias, de F. Bader "Héraklès et les points cardinaux", Minos 18 (1983) 219-256. 
Para el hombre moderno el Oriente ha sido sin duda la zona que ha generado más fantasías, cuando no más temores. De este hecho no debe haber sido ajeno el proceso colonial, así como, más recientemente, ciertos abismos político-ideológicos. La cuestión es que también en este caso una mitología se ha desarrollado vinculada a unas relaciones históricas y a unos determinados intereses. En cambio, en general, para los antiguos griegos el Oriente estaba representado principalmente por pueblos cercanos de alta cultura, de los que recibieron múltiples influencias, mientras, por otra parte, durante mucho tiempo sus intereses estuvieron, si se quiere cuantitativamente, más ligados a Occidente que a Oriente. Y sin embargo no podía faltar tampoco la existencia de una cierta etnología mítica referida al Este.

El fondo oriental del Ponto debió ser por un muy largo plazo una meta lejana y oscura. En él se sitúa no ya un país histórico-mítico como es la Cólquide, sino uno de los símbolos más atractivos de todo el bagaje mítico universal: el llamado vellocino de oro. En este caso el interés mayor no reside en el pueblo mismo, sino en este mágico objeto y por supuesto en la fabulosa expedición de los Argonautas que partió para su captura. Es más, ni siquiera en Apolonio de Rodas a los Colcos se les atribuyen cualidades muy especiales. La leyenda incluso nos hace creer que el vellón les llegó de fuera, y toda la parafernalia mágica se refiere al entorno del vellón, al rey poseedor tanto del objeto como de otros poderes sobrenaturales (su poder, según alguna fuente, depende justamente de seguir siendo el dueño del vellón $)^{27}$ y a su hija, la bruja Medea. Y es básicamente ese objeto y, en todo caso, el viaje de sus conquistadores en torno a lo que se ha desplegado la masa principal de la bibliografía moderna. Ya entre los antiguos se dieron explicaciones de tipo evemerista para el enigma del vellón. Leemos en Estrabón (1.2.39) que el sentido del mito está en la riqueza mineral de la zona, en su oro, su plata y su hierro, y en la misma línea se mueven algunos estudiosos modernos como Ramin ${ }^{28}$. Una tesis más complicada, pero en la que se tienen por supuesto en cuenta algunos datos del mito, es la de $\mathrm{S}$. Eitrem ${ }^{29}$, que relaciona el vellón con el motivo de la lluvia, ya que el objeto mágico fue entregado por Nefele (es decir "Nube") con ocasión de un ritual contra la sequía. Sin embargo, este motivo, de haber sido relevante en algún momento, pronto se perdió en la memoria mítica, dejando de tener un papel en el tema, y simplemente introduce un aspecto más en las dificultades de la interpretación. También R. Roux ${ }^{30}$ había señalado ya una relación con un origen ritual, que por lo demás está ya apuntado en la antigüedad ${ }^{31}$, entendiendo el vellocino de oro como una especie de talismán dentro del contexto de las pruebas de iniciación de la primitiva realeza, tal como, según él, pudo serlo igualmente la tan debatida égida, pero sin olvidar la muy

${ }^{27}$ Cf. en particular Diodoro 4.47.2. La fábula 3 de Higinio, que es citada con frecuencia como testimonio, no recoge este punto.

${ }^{28}$ Op. cit., 139: "L'expédition des Argonautes est une allégorie d'une poussée commerciale en mer Noir et de la quête de l'or de Colchide; divers itinéraires suivis (par Héraklès et) Jason coïncident avec des routes fréquentées par des marchands".

29 Opferritus und Voropfer der Griechen und Römer (Hildesheim 1977) 372.

30 Le problème des Argonautes (Paris 1949).

${ }^{31}$ Cf., por ejemplo, Heródoto 7.197. 
verosímil vinculación con un trasfondo económico y colonial. Por su parte Dion ${ }^{32}$, aun admitiendo que el motivo del vellón tenga un origen ritual, relaciona el tema argonáutico claramente también con el proceso colonizador. Y en el tema ritual ha vuelto a insistir M. Llinares García ${ }^{33}$, una autora para la que la motivación del viaje (que suele ser un escollo aducido contra las justificaciones rituales) estaría justamente incluida en las misma pruebas de iniciación. Otras interpretaciones nos llevan al terreno sicoanalítico e incluso al de la astrología ${ }^{34}$, pero podemos dejarlas de lado sin demasiados escrúpulos.

Posiblemente la mayoría de las propuestas recogidas tiene elementos aprovechables. Cabe perfectamente que en un tema tan complejo como el de los Argonautas haya orígenes rituales de algunos de esos elementos (cf. el sacrificio de Frixo), que sin embargo no explicarían por sí solos la necesidad de un viaje tan largo y azaroso, por lo que también la presencia del soporte económico-colonial, adherido secundariamente, parece innegable. La ubicación de la Cólquide como meta de un ideal justamente al extremo oriental del campo de las ambiciones coloniales griegas en esa dirección es ya de por sí muy llamativa. El vellón de oro, aun admitiendo ese razonable carácter primitivamente ritual ${ }^{35}$, es como tal objeto deseado una lógica conjunción de orígenes diversos, como símbolo también de una riqueza codiciada, tal como probablemente ocurrió con las manzanas de oro de las Hespérides, a las que nos referiremos luego. Por otra parte, y no es difícil explicar cómo, se añadió a este cúmulo temático una contaminación con el tema odiseico, que, tal como se ha visto, se orientaba esencialmente hacia el horizonte occidental. Pero el nombre de Ea (Aîa, Aíaín) reaparece, como sede de Circe y al tiempo como otro término para la Cólquide, dentro del mito argonáutico. Ea se duplicaría por tanto, con una versión al Este y otra al Oeste, y por consiguiente como indiferente en cierto modo a una auténtica orientación, neutralizada en cuanto al espacio o, si se prefiere, en términos de Ballabriga, como una doble ubicación simétrica y opuesta de un tipo nada infrecuente en la mitología. La tesis de una ubicación estricta en el Este para Ea, que fuera apoyada en tiempos por una polémica relación etimológica (a partir, pero por vía secundaria, de la raíz del término para la "aurora") sugerida por E. Schwyzer ${ }^{36}$ y aceptada por Meuli ${ }^{37}$, no ha sido compartida por Lesky y otros. Lesky en concreto se mostró partidario ${ }^{38}$ de remontarnos a una versión primitiva del mito, con huellas aún en Mimnermo, pero en que se trataría también efectivamente de una "Tierra" del Este, la "tierra" (mítica) por antonomasia, morada del Sol y situada a las orillas

\footnotetext{
32 Op. cit., 43 ss.

33 "Mitología e iniciaciones: el problema de los Argonautas", Gerión 5 (1987) 15-42. Su tesis, a pesar de las diferencias de detalle, coincide en lo esencial con la de Roux.

34 Cf. por ejemplo J. Maynadé con su muy imaginativo libro Orfeo y la cíclica expedición de los Argonautas (México 1967), que apunta a una relación con el Carnero (Aries) como signo zodiacal.

35 Sobre el carácter mágico de la lana en ciertas culturas puede recordarse la monografía de J. Pley De lanae in antiquorum ritibus usu (Giessen 1911), citada oportunamente por Llinares García, p. 32 n. 66.

36 "Zwei Vermutungen zu Homer", IF 38 (1917-1920) 158-161. Esta propuesta apenas ha tenido el apoyo de unos pocos (por ejemplo, de Meuli, op. cit., 54). Existe, como se sabe, más de una hipótesis diferente: así, con el soporte de términos como latín auia (Brugmann), con la referencia al concepto de tierra "madre", etc.

37 Op. cit., 54.

38 Ya en su libro Thalatta (Wien 1947), 61, y luego en el artículo ya citado de WS 63, sobre todo 24 ss..
} 
del Océano, y cuya identificación con Cólquide sería posterior. Es más, por ese camino la ubicación oriental se convierte en bastante indiferente y el concepto estaba así disponible para alguna contaminación con un tema colonial adecuado, un proceso del que el doble nombre (Ea y Cólquide) sería un perfecto testimonio. La mezcla de ingredientes se observa muy bien con un motivo como el de las Planctas o Simplégades (Rocas "Entrechocantes"), a las que nos hemos referido ya y apuntado su más fácil explicación. Aparte de poderse ver en ese paso, si se quiere, también un hipotético origen a partir de un tema iniciático, como prueba que el novicio debe superar, el hecho es que su posición en los estrechos que dan acceso al Mar Negro es muy sintomática de una contaminación posterior. Tal como apuntó ya R. Carpenter ${ }^{39}$ y ha recogido luego $\mathrm{R}$. Dion ${ }^{40}$, tendríamos ahí un recuerdo mitificado de las grandes dificultades con que se enfrentaron los primeros navegantes griegos que intentaron penetrar en el Ponto, con motivo en particular de las fuertes corrientes del Bósforo hacia el Mediterráneo, dificultades que sólo se habrían solucionado, según esa hipótesis, con nuevos avances en la técnica naval, es decir con la construcción de la veloz pentecóntoro. De donde procedería por supuesto el relevante papel de la nave Argo, representativa de ese progreso, en la expedición argonáutica. De un modo semejante la ruta argonáutica fue progresivamente enriqueciéndose con una abundante toponimia colonial, hasta alcanzar su mayor auge en la obra de Apolonio de Rodas.

También en las proximidades del Ponto se sitúa otro de los pueblos míticos más notables, el de las Amazonas. Como ocurre con tantas otras poblaciones de carácter fabuloso, su ubicación en las distintas fuentes antiguas es muy variable, y así las encontramos en Licia y Frigia, en las orillas del Termodonte, en Capadocia (Apolonio de Rodas), en Tracia, en la vecindad del Cáucaso y, en algún caso más aislado, incluso en África. Pero aun con esta dispersión geográfica la relación con las orillas pónticas parece un dato seguro, lo que permite buscar una justificación en noticias más o menos vagas y referidas a gentes, seguramente nómadas, de las estepas rusas o asiáticas ${ }^{41}$. En esta dirección han ido las interpretaciones más plausibles: las que creen descubrir un origen a partir de la habilidad como jinetes de las mujeres de estos pueblos, descrita por viajeros de diversas épocas ${ }^{42}$, o bien, por citar una muy ingeniosa hipótesis, por una fácil confusión de sexos a los ojos de quienes veían por primera vez a individuos mongoloides de pequeña estatura y rostro lampiño, excelentes jinetes y arqueros ${ }^{43}$. Pero estas posibles noticias fueron

39 "The Greek Penetration of the Black Sea", AJA 52 (1948) 1-10. Esta tesis de Carpenter ha sido rebatida, en particular por lo que se refiere a su cronología "reciente" para el tema argonáutico, por B. W. Labaree (AJA $61,1957,29-33)$, y puesta muy en tela de juicio por nuevos hallazgos arqueológicos. Pero no es el dato cronológico el que nos atañe estrictamente aquí, por lo que creemos que puede seguir siendo válida una posible relación entre las dificultades del acceso al Ponto y el motivo mítico de las Simplégades.

40 Op. cit., 46 s.

41 Cf. datos sobre las más antiguas representaciones plásticas en H. A. Shapiro, "Amazons, Thracians, and Scythians", GRBS 24 (1983) 105-116.

42 Cf. J. Forsdyke, Greece before Homer, ya citado, 105 ss.

43 Aunque sin aparato filológico alguno, es muy estimulante la lectura del breve trabajo del biólogo K. A. Bisset "Who were the Amazons?", $G \& R 18$ (1971) 150 s., en que se nos recuerdan diversas confusiones 
adornadas con unos rasgos en que, sin embargo, se conservó un aire de masculinidad típico de estas mujeres guerreras y hasta cierto punto hostiles al trato sexual. Los analistas de este mito han señalado el fenómeno de la inversión de los papeles masculino y femenino que se da en él hasta producir una especie de seres andróginos y a la vez una sociedad de características antipatriarcales opuesta a la propia estructura social griega y particularmente primitiva ${ }^{44}$. Sin embargo, parecen erróneos a todas luces los intentos de relacionar a estas gentes, como en el caso de las célebres mujeres de Lemnos, con la tan polémica cuestión del matriarcado. Y resulta quizás igualmente discutible el ver en las Amazonas, como ha hecho algún autor reciente, más que la mera imagen mítica de un pueblo salvaje, belicoso y cazador, la asociación de esta imagen con una censura antifemenina, nacida en una estructura social decididamente masculina como la griega ${ }^{45}$. En cambio, es mucho más fácil y significativa la asociación de las Amazonas con algunos tipos míticos de comunidad en que el varón está excluido, como las Valquirias, y en que la mujer adopta papeles típicamente masculinos, como el del cazador o el guerrero, lo que sin embargo no tiene por qué ser aceptado como un testimonio de una primitiva sociedad matriarcal ${ }^{46}$.

La realidad, pues, parece asomar tras esas figuras míticas, a las que los estudiosos modernos quizás han sobrecargado de simbolismos. Y cabe preguntarse si también otro pueblo mítico como es el de los Etíopes encierra una referencia a una realidad desvelable, aunque sea igualmente bajo la forma de hipótesis. Como ocurría con los Cimerios, los Etíopes míticos no deben haber tenido en principio estrictamente mucho que ver con el pueblo que nosotros, incluso ya desde cierto momento en la antigüedad, nombramos así. Los Etíopes homéricos son un pueblo remoto y privilegiado, al que los dioses visitan con especial agrado ${ }^{47}$. Pero ésta es una caracterización muy común en la idealización de los pueblos míticos y la reencontramos, por ejemplo, en los Hiperbóreos y en cierto modo en los Feacios. Si los héroes homéricos convivían con la presencia divina sin problema alguno, no hemos de sorprendernos de que determinadas comunidades míticas gocen de esa relación de manera especial. Otro rasgo usual, también compartido, es la indeterminación geográfica, puesto que a los Etíopes se les sitúa tanto en el Este como en el Sur o en el

semejantes y que dieron lugar a la creencia en otras "Amazonas", como las que llevaron a la denominación del gran río sudamericano, o entre los esquimales.

44 Cf. W. Blake Tyrrell, Amazons. A Study in Athenian Mythmaking (Baltimore-London 1984). El fenómeno de la "inversión" no es infrecuente como atribuido a pueblos tenidos por salvajes. En el carácter antisocial de las Amazonas, desde la perspectiva griega, ha insistido S. Pomeroy, citada por Tyrrell, $134 \mathrm{n}$. 7. Sobre una relación estrecha entre las Amazonas y los Cimerios históricos cf. R. Ghirshman, "Les Cimmériens et leur Amazones", Actes du VII Congrès de la Fédération Intern. des Associations d'Études Classiques I (Budapest 1984) 47-52. Por lo que se refiere al reciente trabajo de H. Mathieu "Signification des sociétés de femmes dans la mythologie", en Mythe et politique. Actes du Colloque de Liège (Paris 1990) 193-207, bien poco es el provecho que puede sacar un filólogo clásico de su lectura.

45 Cf. R. J. Carlier, "Voyage en Amaxonie Grecque", AAntHung 27 (1979) 381-405.

46 S. Rocca ("Dalle amazoni alla militia Phoebes", en el colectivo Misoginia e maschilismo in Grecia e in Roma [Università di Genova 1981] 97-119) concede un peso quizás excesivo a la ocupación cazadora y, con ello, al culto de Ártemis. En cuanto al tan comentado detalle de la mutilación del seno, como bien cree Rocca, puede tratarse de un simple problema de falsa etimología.

47 Cf. Il. 1.423 y 493 ss., 23.205 ss., etc. 
Oeste. La interpretación de su nombre como "de piel quemada u oscura" no es indiscutible ni mucho menos, puesto que la alternativa "de rostro o mirada brillante" tiene muchos argumentos a su favor y vincularía más fácilmente a este pueblo con el Este y el reino de la luz ${ }^{48}$, aunque la concepción normal entre los antiguos responda más bien a la primera citada. El origen del tema por tanto en noticias o conocimientos de pueblos negroides es poco seguro. La ambigüedad reina de nuevo en los textos homéricos. Así, en el pasaje citado de $\mathrm{Il} .23$ los Etíopes habitan en un típico lugar mítico, "junto a las corrientes del Océano", en $O d .1 .23$ son los pobladores de los extremos del mundo, al estar divididos en aquéllos que viven en los parajes "por donde se pone Hiperión", es decir el remoto Oeste, y aquéllos que viven en el Este, "por donde se levanta", y en $O d .4 .83$ ss., en el contexto del viaje de Menelao, aparecen vecinos de pueblos como los Fenicios y los Egipcios, es decir en una zona geográfica muy precisa ${ }^{49}$. Hay por tanto de nuevo una típica división simétrica, una polaridad ${ }^{50}$, o, si se prefiere, una identificación de opuestos. La primera de las dos interpretaciones etimológicas citadas daría una solución muy satisfactoria (si no tuviera el defecto de que uno puede decidirse por la segunda): tal como la "proximidad" del Sol ascendente puede abrasar la tez, también ocurriría lo mismo por la "proximidad" del Sol descendente ${ }^{51}$. Los Etíopes estarían, pues, en los extremos del eje longitudinal que marca el Mediterráneo. Algunos estudiosos modernos creen, sin embargo, que la referencia a esos dos pueblos polares no sería sino una reelaboración secundaria del mito, a partir de noticias sobre pueblos negroides tanto en Asia como en África, y de hecho Heródoto alude a Etíopes asiáticos (3.94 y 7.70), aunque se refiere a un pueblo muy concreto y súbdito de los Persas, y aún Diodoro (3.2-8) se refiere a dos tipos de Etíopes. En Esquilo (Supp. 284 ss.) se nos habla, de modo muy vago por cierto, de Etíopes en la vecindad de los Indios. Y en la saga troyana Memnón, el caudillo de los Etíopes, es hijo de la Aurora y lógicamente su pueblo debería estar ubicado en Oriente ${ }^{52}$.

Lo más fácil, en fin, y siempre partiendo de una de las dos hipótesis mencionadas, sería deducir que en una versión primitiva se habría situado a los Etíopes en el extremo Este, posiblemente sobre la base de la citada creencia en el poder abrasador del Sol naciente y tal vez de vagas noticias acerca de pueblos orientales de color oscuro, pero más tarde se habría

48 Cf., por ejemplo, Forsdyke, op. cit., 97 ss., y H. Dürbeck, Zur Charakteristik der griechischen Farbenbezeichnungen (Bonn 1977) 177 ss. Este último autor, sin embargo, piensa más bien en el Sur.

49 En cuanto a los Erembos, citados en el mismo texto, no hay ninguna seguridad de que se trate de los Árabes: cf. el análisis del tema en W. von Saden, "Die Eremboi der Odyssee und die Irrfahrt der Menelaos", WS 72 (1959) 26 ss.

50 De lo que deduce J. Haudry (en Peuples et pays mythiques, 21-30) su relación, tal como ocurriría con los Pigmeos, con el ciclo anual.

${ }^{51}$ Cf. en este sentido Ballabriga, op. cit., 108 ss. Recuérdese que Heródoto, cuando trata del desierto al Este de la India donde viven hormigas gigantes, nos dice que allí el Sol abrasa justamente por la mañana, no al mediodía (3.104), y todavía Estrabón se siente obligado a criticar la ingenua idea de que el Sol al sumergirse en el Océano produciría un chisporroteo (3.1.5).

52 En algún momento se produjo una notable contradicción entre la obligada tez blanca de un héroe épico como era Memnón y la supuesta tez negroide de sus Etíopes. Ballabriga menciona en su libro citado (p. 212) las célebres ánforas de la segunda mitad del siglo VI en que contrastan ese Memnón blanco y sus guerreros negros. 
creado una contrapartida en el extremo opuesto, por la típica simetría mítica ${ }^{53}$ y con el lógico apoyo también de los crecientes conocimientos sobre los pueblos africanos, en particular del Sudán, muy en contacto con el mundo egipcio. Pero la idealización de los Etíopes, ahora ya identificados con los africanos, persistió, por ejemplo, en la forma de tradiciones como la recogida por Heródoto sobre la "mesa del Sol" (3.18), en la que se ha querido ver un frasfondo de hechos rituales y que difícilmente puede disociarse de los festines homéricos de los Etíopes, y en su descripción como "los más altos y bellos de todos los hombres" (3.20) y dotados de la extraordinaria sabiduría de la que se hará eco el novelista Heliodoro siglos más tarde. Aun más, cuando se refiere a la expedición de Cambises, Heródoto nos dice que éste no se paró a pensar que "llevaba sus armas a los confines de la

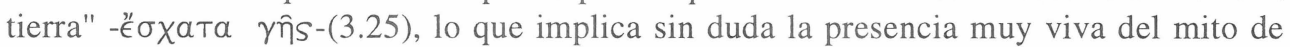
unos hombres situados, como en Homero, en el extremo del mundo.

Con los Etíopes como pueblo señalado por alguna característica física compiten los

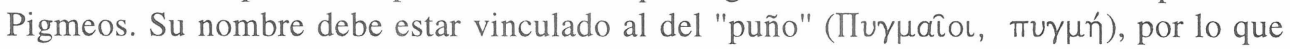
parece una referencia al pequeño tamaño, que es como se ha interpretado tradicionalmente.

En $I l .3 .2$ ss. se nos alude fugazmente al célebre y enigmático episodio de su acoso por las grullas en su huida del invierno en algún paraje cerca de las corrientes del Océano. No nos interesa aquí demasiado el desarrollo legendario de esta notable guerra, que sin duda es una justificación etiológica secundaria ${ }^{54}$, así como tampoco su probable origen folclórico (ved más adelante), y desde luego rechazamos de plano la idea de que las grullas representen simbólicamente a algún pueblo de alta estatura que fuese hostil a unos Pigmeos más o menos reales ${ }^{55}$, lo que nos parece una interpretación demasiado simplista. Se ha apuntado al origen egipcio de esa fábula, aunque esta tesis no la explica y, además, carecemos del propio testimonio egipcio ${ }^{56}$. Janni en una monografía sobre el tema ${ }^{57}$ sitúa en cambio la fuente remota del mito griego en la zona norte de Eurasia, lejos por tanto del África en que estaría su más obvia, pero no obligadamente la más razonable ubicación. La tesis de Janni, que maneja datos de mitología comparada sobre luchas de aves y pueblos enanos ${ }^{58}$, no tiene sin embargo argumentos muy convincentes a su favor, mientras que sí parece haber cierta verosimilitud en la discusión del tema por parte de A. Ballabriga ${ }^{59}$, que insiste en el hecho clarificador de que la concepción subyacente es peyorativa, frente a una tan positiva como la que conocemos en el caso de los Etíopes. La proximidad al Océano situaría a los Pigmeos

\footnotetext{
53 O simplemente por una racionalización, que A. Lesky ("Aithiopica", Hermes 87, 1959, 27-38) atribuye al espíritu jónico.

${ }^{54}$ Está recogida, como se sabe, por ejemplo, en Eliano, HA 15.29, Ateneo, 9.393 e-f, y en Antoninus Liberalis, 16.

55 Cf. J. Pollard, Birds in Greek Life and Myth (Plymouth 1977) 181.

56 Cf. The Iliad: A Commentary, ed. G. S. Kirk, vol. I (Cambridge 1985) 264 s.

57 Etnografia e mito. La storia dei Pigmei (Roma 1978).

${ }^{58} \mathrm{La}$ información puede verse recogida en S. Thompson, Motif-Index of Folk-Literature (6 vols., Copenhaguen 1955-1958) F 535.5.1.

59 "Le malheur des nains. Quelques aspects du combat des grues contre les pygmées dans la littérature grecque", REA 83 (1981) 57-74.
} 
en el ámbito del reino de los muertos o en un equivalente en una vida precaria y miserable, en apoyo de lo cual aduce algunos testimonios atractivos: "Pour les Ethiopiens une vie longue et heureuse se prolonge en quelque sort dans la mort alors que les Pygmées, tout au contraire, sont comme morts déjà de leur vivant" (p. 71). La conclusión de Ballabriga (p. 73) responde a un principio que aquí hemos defendido reiteradamente, el de que el mito es un eco de la realidad, por supuesto transformada imaginativamente: "La solution la plus réaliste consisterait donc à admettre qu'à l'occasion d'une donnée égypto-éthiopienne -relative aux Pygmées réels, très vaguement connus des Grecs par ouï-dire- s'est investi un imaginaire de nature archétypale, qui d'emblée déborde la donnée réelle et a pu ailleurs s'actualiser sans un tel catalyseur". Podemos sentirnos recelosos de aceptar esta interpretación en todos sus componentes, pero no parece existir otra que hoy por hoy la desplace con mayores méritos. Y sobre todo si se trata de una propuesta tan poco consistente como, por ejemplo, la de J. Haudry, que integra a grullas y Pigmeos en su concepción cósmica de los ciclos temporales ${ }^{60}$. La noticia de que los Pigmeos viven en cavernas puede deducirse ya de Hesíodo (fr. 150 M.-W), está recogida, desde luego para los Pigmeos supuestamente reales, en Aristóteles (HA 8.597 a 6) y puede relacionarse tanto con una concepción originalmente ligada al mundo mítico subterráneo como con noticias sobre pueblos trogloditas, de los que se sabía habitaban precisamente algunos en el Alto Egipto. En diversas mitologías existen estirpes de enanos, más o menos deformes, con gran frecuencia moradores de un mundo subterráneo y también con frecuencia de conducta maléfica, con una asociación muy usual entre la deformidad y la maldad ${ }^{61}$. Y, en el caso griego, de ciertas noticias antiguas se deduce claramente que los Pigmeos eran imaginados como un pueblo en un estadio agrícola ínfimo, en lucha por la supervivencia, lo que puede explicar hasta cierto punto su acoso por aves migratorias como las grullas, consagradas a Deméter y vinculadas por tanto a la agricultura $^{62}$. Heródoto por su parte nos transmite una tradición acerca de unos exploradores norteafricanos que se arriesgaron a descender por el interior del continente, primero en dirección Sur y luego hacia el Oeste, atravesando "la región de las fieras" y el desierto, hasta encontrar finalmente a unos hombrecillos en un paraje que los exploradores conjeturaron como perteneciente a la cuenca del Nilo $(2.32 \mathrm{~s}$.). Es notable que en ningún momento nuestro autor les aplique a esos hombrecillos el nombre de Pigmeos, lo que debe entenderse, tal como ocurre en Estrabón, en el sentido de que ese concepto se consideraba ya como restringido a la esfera del mito, a diferencia visiblemente de lo que sucede en Aristóteles y

\footnotetext{
60 En Peuples et pays mythiques, 22 ss.: "C'est l'image de l'affrontement annuel des principes cosmiques antagonistes, le principe diurne et le principe auroral (simbolizado por las grullas como "des oiseaux blancs au col rouge") unis contre le principe nocturne" (sc."des personnages noirs"). Todo ello dentro de una "mythologie de l'hiver: l'hiver comme combat entre les forces du jour et celles de la nuit" (p. 26).

61 Cf. art. "Enano" en J. Chevalier-A. Gheerbrandt, Diccionario de los símbolos (trad. esp., Barcelona 1986). Que en la mentalidad griega también había una asociación entre enanismo, deformidad e inferioridad lo atestigua Aristóteles, PA 686 b 3-32. Sobre la presencia en distintos folclores de relatos equiparables al episodio homérico citado cf. también A. Scobie, "The Battle of the Pygmies and the Cranes in Chinese, Arab, and North American Indian Sources", Folklore 86 (1975) 122-132, y "A Further Note on Pygmies and Cranes in North America", ibid. 88 (1977) $86 \mathrm{~s}$.

62 Cf. las referencias dadas en el artículo citado de Ballabriga.
} 
después en Plinio ${ }^{63}$, con un claro proceso de historización del dato legendario. Pero es evidente que esa noticia recogida en Heródoto atestigua, aunque no sea explícitamente, una asociación con una entidad como la de los míticos Pigmeos y la conciencia también de su ubicación en el Sur, y a la vez coincide en cierto modo con algunas informaciones contenidas en documentos egipcios que muestran el conocimiento de los Pigmeos africanos ya en el tercer milenio a. C. ${ }^{64}$ Para Ballabriga, en su artículo ya citado (p. 73), la conclusión es ésta: el mito habría exaltado una noticia justamente de origen africano, con una interpretación por tanto en las antípodas de la propuesta por Janni. El nombre, si aceptamos (y lo hacemos con gusto) esta base real, aparece como una metáfora, es decir con la aplicación de uno de los mecanismos lingüísticos habituales de la conducta mítica. Y de este modo rechazaríamos, al menos en este caso concreto, una posición como la de Haudry, ya citada, para el cual además desde una perspectiva metodológica "peu importe que les Pygmées soient les Négrites, ou des Nains imaginaires: l'essential...est la signification, non la réalité"65. Y, sobre todo, si esa "signification" se deduce de una teoría tan poco aceptable como la de este autor. En realidad no nos parece relevante que la noticia sobre estos pueblos de corta talla sea de origen exclusivamente africano o se admita igualmente la posibilidad de alguna información sobre los Pigmeos asiáticos, aunque esto nos parece mucho menos probable.

Desde nuestro punto de vista, pues, tanto las Amazonas como los Pigmeos, y tal vez también los Etíopes, revelan un trasfondo de noticias vagas pero reales. Es casi seguro que las poblaciones de Pigmeos africanos se extendían en la antigüedad por una zona mucho más amplia que la actual, en el centro del continente, y por consiguiente tal vez más cerca de la costa Norte. A través de los Egipcios y en general de los pobladores costeros, como en la información proporcionada por Heródoto, debieron llegar rumores a los viajeros griegos desde fecha muy antigua. Y de ahí a su idealización, esta vez más negativa que positiva dadas sus características, no hubo más que un fácil paso.

En cambio, en el caso de los Feacios las posibilidades de un origen en algún pueblo determinado nos parecen mucho más escasas. Es más, el episodio de los Feacios odiseicos tiene unas marcas que responden de muy cerca a lo que aquí hemos entendido como utopía político-intelectual, aunque por supuesto, y a pesar de la esmerada construcción del episodio y la notable estructuración idealizante de la sociedad feacia, los elementos puramente míticos sean palpables. Los Feacios son un pueblo dichoso, si bien dividido tan rígidamente en clases como la propia comunidad de Ítaca; viven, como también los Eólidas, en perenne fiesta y recreo, con un lujo envidiable, y los dioses no sólo los visitan con agrado, como a los Etíopes, sino que los admiten como auténticos "vecinos" o iguales

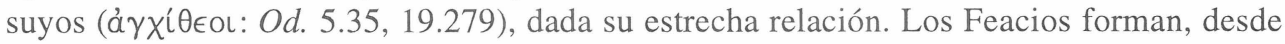
el punto de vista de la época, una sociedad perfecta, con una jerarquización y un orden social

\footnotetext{
63 Cf. F. Colin, "Le sens du mot pygmaios: fables antiques et confusions actuelles", AC 59 (1990) 193-197.

64 Cf. los datos bibliográficos en L. Muellner, "The Simile of the Cranes and Pygmies. A Study of Homeric Metaphor", HSCPh 93 (1990), en particular p. 100.

65 En su contribución citada a Peuples et pays mythiques, 23.
} 
estable, por contraste con la turbulenta Ítaca, y mantienen un curioso equilibrio entre la hospitalidad y la xenofobia ${ }^{66}$, que posiblemente los Griegos veían como un modelo digno (aunque muy difícilmente) de imitar ${ }^{67}$. No se trata por tanto del ideal simplista de un pueblo natural, al estar lejos del concepto del "buen salvaje", que también funciona en la cultura griega y que estaría algo más cerca de concretarse, por ejemplo, en los Etíopes o en los Escitas, por lo que yerran quienes ven en los Feacios esencialmente sólo la cara positiva, el perfecto asilo para el héroe errante ${ }^{68}$. Una notable función que les está atribuida es la de llevar generosamente a cualesquiera viajeros hasta su remoto hogar, puesto que su aislamiento es bien subrayado a lo largo del texto. Y sin embargo, a pesar de que suele olvidarse, en ningún momento se nos dice de modo plenamente expreso que habiten una isla $^{69}$. Pero es evidente que en ellos tiene uno de sus más perfectos ejemplos la insularidad mítica, de la que ya hemos hablado, en el sentido de un mundo aparte, sin otro contacto, en este caso, con el resto de la humanidad excepto esos servicios marítimos de su generosa поцти́. La ambigüedad del texto citado a este respecto ha permitido tanto las ubicaciones derivadas de la interpretación isleña, como la atestiguada en Tucídides (Corcira: 1.24 s. y 3.70) y defendida modernamente a pesar de todos sus graves inconvenientes por Bérard ${ }^{70} \mathrm{y}$ por Dion ${ }^{71}$, como la continental, en el caso de un Moulinier ${ }^{72}$ (en las costas de la Cirenaica), y por supuesto también la de la mera referencia a un lugar de fábula (Welcker y otros). Por otra parte, los Feacios se nos presentan como emigrantes y colonos, que en tiempos huyeron de la incómoda vecindad de los Cíclopes, con lo cual se establece entre

66 En su inhospitalidad ha insistido con bastante razón, pero de un modo a la vez exagerado, G. Rose ("The unfriendly Pheacians", TAPhA 100, 1969, 387-406), que casi sólo ve en Esqueria una especie de último banco de pruebas para el héroe.

67 "Un modèle reconnaissable de la civilisation grecque", dice H. Mathieu en Peuples et pays mythiques, 141, aunque dejando un tanto de lado elementos no tan positivos en esa imagen. Ferguson (Utopias of the Classical World, London 1975, 14 s.) recuerda oportunamente la observación de Toynbee de que las utopías suelen surgir cuando se siente la necesidad de defender un orden social en peligro, que en este caso él identifica con las viejas monarquías sometidas a la presión de la nobleza. En la idea de Feacia como contrafigura políticosocial de Ílaca ha insistido también T. Krischer en su excelente artículo "Phäaken und Odyssee", Hermes 113 (1985) 9-21, donde se lee una acertada crítica a quienes, como Woodhouse y otros, sólo ven en el episodio aspectos secundarios de carácter, por ejemplo, folclórico.

68 Cf., por ejemplo, C. P. Segal, "The Phaeacians and the Symbolism of Odysseus' Return", Arion 1.4 (1962) 1764, o H. J. Kakridis, La notion de l' amitié et de l' hospitalité chez Homère (Thessaloniki 1963) 93.

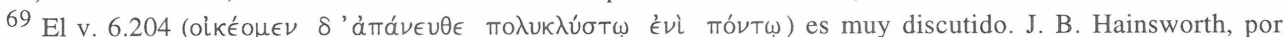
ejemplo, en su comentario en la edición Mondadori de la Odisea (vol. II, 1988, 4. edición), interpreta que se trata de una isla, que es lo más probable.

70 Les Phéniciens et l'Odyssée I (Paris 1902-3) 574 ss. Otras localizaciones célebres son las de la Creta minoica (W. Leaf), Tartesos (R. Henning) y, en fecha más reciente, Chipre (A. D. Fraser, que en su artículo "Scheria and the Phaecians", TAPhA 60, 1929, 155-178, hizo además una excelente historia de la cuestión).

71 Aspects politiques, citado, 109. Es difícil imaginar cómo un historiador de la antigüedad puede llegar a conclusiones tan osadas como la de que el nombre de los Feacios no sería sino una especie de anagrama de los Focenses, con los que estaría representada la gama de los colonizadores jónicos, tan apreciados por el poeta, frente a sus odiados Corintios.

72 Cf. de éste las pp. 109 ss. de su libro citado. Los argumentos manejados para la defensa de esta tesis son todos muy precarios naturalmente, pero nos parece en especial notable el de la distancia respecto a Ogigia, que Moulinier, siguiendo a Bérard, sitúa en las cercanías del Estrecho de Gibraltar: así los datos míticos en su mutuo apoyo se transforman en datos geográficos reales, por más que la metodología se resienta. 
ellos y Odiseo una vinculación muy particular, así como el contraste más acusado posible entre la barbarie de los Cíclopes y la civilización feacia. El carácter imaginario del relato, subrayado en cambio por el citado Welcker, por Eitrem, Germain ${ }^{73}$, J. Peigney ${ }^{74}$ y otros, y tan próximo, como tantos episodios odiseicos, a la esencia del cuento popular, es la conclusión más convincente, como una creación utópica, incluso como la primera utopía de la literatura griega y, por ende, de la occidental. Ese carácter fabuloso se revela de un modo particular, por ejemplo, en el motivo del sueño de Odiseo durante el viaje nocturno que lo devuelve a Ítaca, que no puede menos de recordar el viaje de Aristeas, del que hablaremos después ${ }^{75}$. Pero es esa nota colonial, en la que nos gustaría insistir, sobre todo porque no suele tenerse muy en cuenta. Durante una larga etapa en que los Griegos tuvieron como meta un tipo de navegación comercial-colonial una utopía como ésta, en que el deseo de una tierra acogedora y próspera era acuciante, debió funcionar como estímulo y a la vez como modelo perfecto. El motivo mismo de las prodigiosas naves de los Feacios recuerda demasiado los atributos sobrenaturales de la Argo como para no concluir que todas ellas representan de algún modo las preocupaciones navales de quienes se arrojaban a tales arriesgadas empresas. De este modo la hazaña argonáutica y los, mucho más erráticos, desplazamientos de Odiseo se complementan, al llenar las dos direcciones relevantes de la cuenca mediterránea, hacia el Este y hacia el Oeste respectivamente. Aunque cabe añadir que el sentido utópico de la comunidad de Esqueria convierte en irrelevante esa posición occidental, que emana sólo del contexto del poema homérico. Por otra parte, según los cálculos hechos por Austin ${ }^{76}$, el viaje nocturno de Esqueria a Ítaca tiene además la particularidad de ocurrir cuando ya se ha entrado en la estación hostil a la navegación, es decir en lo que luego se llamará mare clausum, lo que refuerza el carácter extraordinario de estas naves y sus derroteros. Como dice Austin (loc. cit.), "their supernatural power might seem superfluous when Odysseus has already eluded every kind of peril by his own wits, but Homer's maritime audience would have enjoyed the coincidence that the storm that closed the paths of the sea for the year should have cast Odysseus among a people whose skills were happily not subject to the season. The Phaiakians secure Odysseus' passage across the treacherous winter sea because the weather has now made human navigation suicidal". Las escasas horas del viaje nocturno han llevado, ya desde la antigüedad, a la convicción de que Esqueria estaba a escasa distancia de Ítaca, y de ahí una identificación con una isla como Corcira, con el fomento de un motivo de orgullo de los habitantes locales,

\footnotetext{
73 Cf. sobre todo su Genèse de l'Odyssée (Paris 1954).

${ }^{74}$ En su artículo de tan expresivo título "La Phéacie, terre poétique", en Peuples et pays mythiques, 47-56. Las derivaciones iniciáticas y chamánicas a que el autor se refiere también (cf. igualmente A. Thornton, Peoples and Themes in Homer's Odyssey, London 1970, 20 s.) nos parecen en cambio más discutibles.

75 Segal, art. cit., ha subrayado la función de los Feacios como transición entre el mundo mítico y el real.

76 En su libro ya citado Archery at the Dark of the Moon, 243 sobre todo. Este investigador defiende las precisiones temporales de la Odisea, en línea con las opiniones de Wilamowitz y otros y contra interpretaciones posteriores divergentes. No podemos seguirle en cambio en sus elucubraciones sobre cultos solares y lunares que cree descubrir en el texto, si bien ha de reconocerse que las propuestas de Austin son mucho más moderadas en este terreno que las que se leen en otros autores.
} 
olvidando, como ya se señaló, este carácter prodigioso de la nave y por tanto la imposibilidad de controlar su velocidad.

En Occidente por supuesto hay que situar igualmente el ámbito de las Hespérides, tal como su nombre subraya. Hesíodo las hace también hijas de la Noche (Th. 211 ss.) y en consonancia las hace hermanas de una serie de criaturas siniestras y negativas, entre ellas la Muerte. Alguna otra versión las convierte en hijas de Atlas y Hesperia, lo que parece significar que persiste esa ubicación occidental. El propio Hesíodo (Th. 215 s.) especifica que es "más allá del Océano" donde guardan "las manzanas de oro y los árboles que producen esos frutos", lo que, unido a los otros datos, puede interpretarse como una situación ultraoccidental, confirmada por los vv. 333 ss., en que se lee que la sierpe o dragón que protege las citadas manzanas vive "en el hondón de la tierra sombría" ('є $\rho \epsilon \mu \nu \hat{s} \quad \kappa \epsilon u ́ \theta \epsilon \sigma \iota$ yaíns). Pues tal como hemos visto, no es infrecuente que el límite extremo aparezca en realidad como una cierta variante del mundo subterráneo, o a la inversa si se prefiere, por lo que es evidente que las Hespérides tienen su sede en ese ámbito confuso que es a la vez el Occidente más remoto imaginable, un Occidente extrahumano, y el Más Allá soterraño. En cambio, no es ya tan fácil de aceptar que en su origen el mito ubicase las Hespérides en un lugar tan preciso como el Estrecho de Gibraltar ${ }^{77}$, tal como hace, por ejemplo, Dion (op. cit., p. 142): "Pour les Hespérides comme pour Ulysse, l' 'au-delà de l'Océan' est la rive africaine du détroit, celle que domine Atlas, la haute montagne personnifiée par le géant du même nom...". Tal como luego se produjo un nuevo traslado hasta la Cirenaica, por la presión cartaginesa en opinión del mismo Dion, hubo posiblemente y como una variante secundaria, igual que en los relatos odiseicos, una identificación concreta, pero los textos citados son determinantes en cuanto a la relación con un lugar esencialmente extrageográfico, es decir mítico.

Algo semejante ocurre con el simbolismo de las manzanas de oro. Parece tener razón Ballabriga ${ }^{78}$ cuando rechaza la simple imagen de un árbol y unos frutos: "le 'terrible serpent' de la Théogonie atteindrait plutôt des proportions cosmiques en gardant tout un étage cosmique à la fois primordial et souterrain". El mito de las Hespérides no tiene el talante de los que ofrecen una meta atractiva, interpretable como un desideratum; antes al contrario, al menos en sus componentes hesiódicos posee un aire sombrío y su relación con la muerte es indudable. La interpretación como símbolos de fecundidad, lo que sin embargo no es absolutamente imposible a través de la imagen del árbol y sus frutos y respondería a la vieja tendencia a unir los opuestos y a sintetizar las contradicciones, se da ya en los textos clásicos ${ }^{79}$, pero tiene visos de ser una reelaboración, tal como lo es su ingreso en los mitos olímpicos y en ocasión de las bodas de Zeus y Hera. Ya ahí el lugar se ha transformado en un paraíso sensual y florido, por lo que tampoco sorprende que en cierto momento se produjese esa su identificación con la entonces próspera Cirenaica. Pero las

\footnotetext{
77 Por no hablar de las Islas Canarias, según la propuesta de J. Régulo: cf. M. García Teijeiro, "Escatología griega e Islas de los Bienaventurados", en Serta Gratulatoria in honorem Juan Régulo I (La Laguna 1985) 271.

${ }^{78}$ Le soleil, 83.

79 Por ejemplo, Eurípides, Hipp. 742 ss.
} 
Hespérides han sido situadas en otros parajes, por lo que Plinio $(H . N .5 .31)$ puede bien decir al referirse a ellas aquello de "vagantibus Graeciae fabulis", una sentencia que sin embargo, como ya sabemos, vale para la casi generalidad de la geografía mítica. Las encontramos también en la cuenca del río Erídano, identificable tanto con el Po como con el Ródano. Y no nos debe extrañar que las manzanas de oro se interpretasen sobre todo como frutos agrícolas idealizados, o bien, aprovechando la ambigüedad del término griego, como "ovejas"80. Y modernamente se ha ido incluso más allá. Así Ramin (op. cit., pp. 85 ss.) piensa en el ámbar: si hubo una ruta atlántica para este producto, desde el Báltico a través del Estrecho de Gibraltar, y controlada en sus últimas etapas por Cartagineses y Fenicios, una estación de tal ruta bien pudo estar en un lugar como Bengasi. Verdad es que en Apolodoro (2.5.11) las Hespérides son relacionadas con los Hiperbóreos, que, como veremos, han sido a veces vinculados justamente con el ámbar, pero de esta versión tan aislada, además de muy oscura para nosotros, no es lícito deducir esas consecuencias.

De los Hiperbóreos parece haber tratado por extenso Hecateo de Abdera, uno de los autores practicantes, como Evémero, Teopompo, etc., de la geografía utópica en los albores del Helenismo. Seguramente Hecateo insistía en sus aspectos de pueblo feliz, como encarnación de un ideal filosófico, dentro de las concepciones humanísticas del siglo IV, aunque aprovechando aquellas noticias míticas útiles para su exposición. Pero se trataba ya desde luego de una construcción intelectual, que no tenía por qué recordar demasiado el antiguo mito. Incluso los situaba no en el Norte remoto, en tierra firme, sino, como era casi inevitable en una utopía, en una isla, en este caso "frente a la tierra céltica" para conservar al menos alguna conexión con la tradicional ubicación nórdica ${ }^{81}$. Porque los Hiperbóreos, como ya su nombre muestra, eran relacionados desde siempre con el Norte enigmático y continental, del cual ni siquiera la expedición de Piteas llegó a dar unas clarificadoras informaciones sobre su conformación costera. Un texto como el de Heródoto 3.115 revela la ignorancia antigua sobre el Norte europeo y a la vez la curiosidad insatisfecha sobre el origen de productos como el estaño y el ámbar.

Aparentemente los Hiperbóreos serían los habitantes de algún paraje más allá, es decir más al Norte, de donde sopla el viento Bóreas. Este viento se originaba en los llamados Montes Ripeos, entendidos como la barrera natural que separaba de algún modo el Norte imaginable y vagamente accesible de un más allá inimaginable, quizás a partir de noticias sobre el Cáucaso, los Urales o las cadenas de elevaciones de Asia Central ${ }^{82}$. Claro es que,

\footnotetext{
${ }^{80}$ Cf. Diodoro $4.26 \mathrm{~s}$.

$81 \mathrm{Cf}$. los datos ofrecidos por Rohde en su mencionado libro sobre la novela, 226 ss., así como Ferguson, $o p$. cit., 122-129 sobre todo. También son interesantes los trabajos de R. Dion, "La notion d'Hyperboréens; ses vicissitudes au cours de l'antiquité", BAGB (1976) 143-157, y J. Desautels, "Les monts Rhipées et les Hyperboréens dans le traité hippocratique Des airs, des Eaux et des Lieux", REG 84 (1971) 289-296. Los textos griegos antiguos sobre los Hiperbóreos están oportunamente recopilados en G. Colli, La sapienza greca I (Milano 1977) 322-433.

82 Ballabriga, por ejemplo (Le soleil, 244 s.), cree que los Montes Ripeos podrían ser una proyección imaginaria del Cáucaso o incluso de un fantástico conjunto formado por el Cáucaso y los Alpes. Lo primero se desprende de su tesis orientalista, a la que nos referiremos luego; lo segundo es muy razonable, de modo que podemos entender que Ripeos significaba una referencia a toda cordillera nórdica y remota.
} 
como siempre, una indicación como esta nórdica debe tomarse en un sentido muy amplio, y Ballabriga, por ejemplo, puede insistir con razón en su libro tantas veces citado en que tal orientación engloba en cierto modo posibles referencias que nosotros situaríamos tanto al Oeste como, sobre todo, al Este (pp. 232 s.): "Le Grand Nord est alors plutôt un nord-est qu'un nord-ouest". Sin embargo es seguramente exagerado afirmar, tal como lo hace este mismo autor (p. 240), que las noticias antiguas sitúan a los Hiperbóreos en el Este, achacándoles paradójicamente una precisión que antes les ha negado y de acuerdo con su discutible tesis de que "l'axe nord-sud fondamental est un axe oriental qui joint la Scythie à l'Ethiopie" (p. 233). El Bóreas era el viento frío del Norte o Noroeste, por lo que, como se ve en una descripción del Olimpo ( $O d .6 .43$ ss.) en que lógicamente se produce una neutralización sin gravosos fenómenos meteorológicos, allí "no sopla el Bóreas". Por lo cual era también obligado que, al estar más allá de donde sopla este viento, los Hiperbóreos tuviesen una existencia feliz, de la que se hace eco, por ejemplo, Píndaro en su décima Pítica: son pacíficos y dichosos, están libres de toda enfermedad durante su larga vida y habitan una tierra extremadamente feraz, con dos cosechas anuales y de clima placentero. Una idealización que Baquílides, en un pasaje ya citado (3.59), lleva al extremo, al identificarlos con un paradisiaco Más Allá equivalente a la Isla de los Bienaventurados. Y, como no podía ser menos, y en esto nos recuerdan a los Etíopes y Feacios, las noticias sobre ellos nos informan de que son gratos a los dioses y de que Apolo los visita de un modo particular.

La consecuencia para nosotros es clara. Ese Norte remoto, más allá del Norte geográfico natural, es un lugar utópico, totalmente ajeno al Norte brumoso y helado que ya Heródoto (4.31) e incluso, como indicábamos, todavía Aristóteles imaginaban como inhabitable. Y no es sorprendente que un pueblo y un lugar así fuesen el tema de un antiguo poema, en que los rasgos prodigiosos dominaban y obra de un supuesto Aristeas de Proconeso ${ }^{83}$. Según nos informa Heródoto (4.33 ss.), Aristeas en su Arimaspea narraba cómo, caído en una especie de trance o éxtasis por obra de Apolo, en que era como si estuviese muerto en vida, viajó hasta llegar al pueblo de los Isedones, de los cuales proporcionaba verosímilmente los datos que recoge Heródoto; ésos a su vez le informaron sobre otros pueblos de tierra adentro tales como los Arimaspos, dotados de un solo ojo, y los Grifos, guardianes de oro (como los Nibelungos germánicos), todos ellos extremadamente belicosos, y, al fin, sobre los Hiperbóreos, pacíficos por contraste y vecinos de un mar que no nos cuesta nada sospechar que en el texto de Aristeas fuese el Océano mítico ${ }^{84}$. Del supuesto poema de Aristeas se nos han conservado sólo unos pocos hexámetros ${ }^{85}$ y pudo ser compuesto hacia el siglo VII o

\footnotetext{
83 Sobre el tema cf. la monografía de J. D. P. Bolton Aristeas of Proconnesus (Oxford 1962), cuya metodología censura Ballabriga (libro citado, 232 n.). Cf. también K. Meuli, "Scythica", Hermes 70 (1935) 121-176, en especial 153 ss. Aristeas fue verosímilmente "eine mythische Figur des Apollonkultes, wie Olen und Abaris", en palabras de O. Crusius, art. "Hyperboreer", en el Lexikon de Roscher, I 2, 2814.

84 Esta oposición no puede menos de recordarnos la que se da entre los Feacios y los Cíclopes. También en la calidad de los pueblos míticos puede procederse a una polarización. Pero más tarde esta oposición se olvidó: cf. Bolton, op. cit., $23 \mathrm{~s}$.

85 Los textos y los testimonios están recogidos en el libro citado de Bolton, 207-214.
} 
ya en el VI. Su viaje en trance nos recuerda el viaje nocturno en sueños de Odiseo de Esqueria a Feacia, pero sobre todo la muerte aparente que da acceso a Ultratumba en el mito de Er en la República platónica y que es un modo de viajar en muchas culturas al reino de la fábula y el mito. Es más, ha llegado a sospecharse que estamos ante una típica actuación chamánica o milagrera ${ }^{86}$. Pero a la vez en esa obra no cabe duda de que se contenían ciertas informaciones geográficas y etnográficas y que no es sorprendente que llamara la atención de Heródoto. Para Bolton (p. 75), que es posible que exagere un tanto este aspecto y que confía posiblemente demasiado en la realidad del viaje de Aristeas, su poema "comprised someone's first-hand observations of the Eurasian hinterland, and items of Asiatic folk-lore interpreted, not unnaturally, in terms that a Greek would understand". Con lo que tendríamos el primer documento en que se nos revelaría ya el interés de los Griegos hacia los rumbos del Norte, más allá de las usuales noticias sobre los Escitas, pero dentro de un indiscutible contexto mítico.

El nombre de los Hiperbóreos y su interpretación tradicional ofrecen razonables dudas. No han faltado quienes crean, en cuanto al término, en una deformación provocada por una etimología aberrante sobre la base del nombre del viento del Norte. El propio Heródoto (loc. cit.) relaciona con ellos $\Pi \epsilon \rho \phi \epsilon \rho \in ́ \in S$ en el sentido de "portadores" de las célebres ofrendas que los Hiperbóreos hacían llegar hasta Delos, al santuario de Apolo. Esta palabra podría proceder del macedónico, según una ya vieja propuesta de Ahrens. Y, a su vez, estas ofrendas o primicias han sido interpretadas como una mitificación de algún precioso producto de origen nórdico, en concreto el ámbar, que era transportado hasta el Mar Negro y el Egeo por vías fluviales desde el Báltico ${ }^{87}$. Un artículo valioso como éste habría hecho idealizar su lugar de origen, que, como nos informa Heródoto, se desconocía. La ruta seguida por esas presuntas ofrendas anuales parece haber sido en principio la descrita por Heródoto, por una vía próxima al Adriático y en la que Dodona pudo tener una cierta importancia ${ }^{88}$. Tal ruta comercial habría sido sacralizada con el paso del tiempo ${ }^{89}$. Todavía Apolonio de Rodas (4.596 ss.) sitúa el origen mítico del ámbar en la cuenca del curso superior del Erídano y atribuye a los Celtas una tradición propia sobre ese mismo origen. Apolonio confunde hasta cierto punto el Erídano con el Ródano, y su alusión a un lago, de donde fluiría el ámbar, puede ser un eco de noticias borrosas sobre el mar nórdico y al tiempo tal vez sobre los lagos alpinos. Sea como sea, el origen del ámbar al menos en cierto momento fue imaginado, y con buenas razones, en un Norte más occidental de lo que

\footnotetext{
86 Tesis de Meuli, que está hoy todavía muy extendida. Bolton (op. cit., 125 ss.) la discute y matiza.

${ }^{87}$ La hipótesis del ámbar fue expuesta ya por Welcker (cf. Mayer, art. cit., 2829, con una actitud crítica) y ha sido recuperada por algunos autores más recientes como Ramin (op. cit., 70 s.).

88 Se han encontrado huellas de esta ruta del ámbar en el valle del Mati, en Albania, desde fechas muy antiguas. La otra vía, posterior, es la descrita por Pausanias (1.31.2), por el Mar Negro. Cf. al respecto G. B. Biancucci, "La via iperborea", RFIC 101 (1973) 207-220.

89 El carácter piadoso de los Hiperbóreos es una nota destacada y ha llevado, por ejemplo, a A. J. van Windekens ("Les Hyperboréens", RhM 100, 1957, 164-169) a la tesis de un círculo religioso, que englobaría en algún punto del Norte griego a Helenos y Macedonios o Traco-frigios y con tendencias definidamente órficas. Pero no hay que olvidar que la piedad religiosa es un rasgo típico de muchos pueblos míticos, como hemos visto en el caso de los Etíopes o los Feacios.
} 
cree Ballabriga. La mención del ámbar y a la vez de los Hiperbóreos en el ya citado fragmento 150 de las Eeas hesiódicas sería un dato relevante en favor de esta tesis, pero en el estado del texto que poseemos no parece establecerse explícitamente relación alguna. En cuanto al papel desempeñado por Apolo en la leyenda de los Hiperbóreos, es otro elemento notable y algunos han sugerido que respondería a vagas noticias sobre la importancia del culto del Sol entre los distantes pueblos germánicos ${ }^{90}$, por más que la identificación entre Apolo y el Sol no sea muy antigua entre los griegos.

El mito de los Hiperbóreos, pues, si aceptamos esta atractiva tesis de su relación con la vía comercial del ámbar, nos haría alinear el tema junto a otros varios que nos han mostrado que es muy verosímil una explicación de un hecho mítico en función de unos intereses vitales. Con frecuencia estas hipótesis no pueden hallar una demostración, pero forman parte de un intento de explicación del fenómeno mítico, quizás no en su conjunto, pero sí en algunos de sus capítulos más fascinantes.

${ }^{90}$ Cf. Ramin, ibid. 
